\title{
The Saami Peoples from the Time of the Voyage of Ottar to Thomas von Westen
}

\author{
CHRISTIAN MERIOT*
}

The history of the discovery and understanding of the Saami peoples can be divided into three periods. The earliest record goes back to Tacitus, who in his Germania describes the Fenni as savages, since they had neither weapons nor horses, dressed in animal skins, slept on the ground, and used bone weapon tips for hunting because of their ignorance of iron. About A.D. 150 Ptolemy wrote of the Phinnoi. Not until the De bello gothico of Prokopius, towards A.D. 550, were they called "Skrithiphinoi", an allusion to their ability to slide on wooden planks; in the De origine artibus Getarum of Jordanes, a contemporary of Prokopius, they are referred to as Screrefennae and Sirdfenni. This prehistory of the Sammi peoples can be said to end with the History of the Langobards by Paulus Diaconus (Varnefrid) about A.D. 780, which adds to the previous knowledge of the Scritobini or Scritovinni the information that they used reindeer (though not named thus explicitly) and that they lived in a country of the midnight sun in summer and of endless darkness in winter.

The latest period of discovery began in the eighteenth century, through scholars in various disciplines, and through countless travellers passing through more for recreation than for reasons of serious exploration.

Between these two phases, there was a long transition period beginning with Ottar's account of his journey in Lappland (dated at the end of the ninth century, about 890), and ending at the turn of the seventeenth into the eighteenth century with the first scientific works of learned men such as Schefferus (1621-1678) and of missionaries such as von Westen (16821727). The latter were certainly more driven by the demands of administration and evangelism, but their investigations, while not always directly fired by a zeal for pure knowledge, show a concern for accuracy and a critical appreciation from which can be drawn the indispensable foundations of ethnological observation.

In the eight centuries between Ottar and von Westen there were many people whose calling led them, through journeys they undertook themselves or initiated for others, to reveal gradually the Saami society of their time. Their accounts are precious today even if looked at through the biased spectrum of their prejudices. It is impossible to discuss all the Western discoveries about the Saami. within the confines of this paper. Its aim, after listing the main sources available, is to weigh up the main points of interest and point out where these sources can add to our knowledge of the Saami people and the major changes they underwent when "colonization" or "civilization"' forced them into contact with the West.

\section{THE SOURCES}

The main sources of information follow, in chronological order.

Ottar (Ohthere) was a rich Norwegian landowner, bailiff, and teacher during the reign of the Viking King Harald Haarfager (Fairhair), at the end of the ninth century. In the course of a business visit to England, Ottar related to Alfred of Wessex (king from 871-901) the story of a voyage he had made to. Helgeland, in the north of his homeland. During this voyage he rounded the Kola peninsula to Duna. King Alfred included Ottar's account in his translation of Orosius, towards 890. The Anglo-Saxon text, with an English translation, was published in a modern edition by Joseph Bosworth (1855).

Ottar's account is full of information on the Saami way of life and their contacts with farmers in northern Norway. For example, the Saami, above all fishermen and hunters, had developed the domestic breeding of reindeer (and used decoy reindeer, among other means, to capture wild reindeer). The Saami further north were semi-nomads: they fished at sea in summer and hunted in winter. Vikings such as Ottar owned reindeer which they gave to the Saami to care for. The Saami paid the Vikings taxes in kind, in the form of skins, bird feathers; walrus teeth, whalebone, and ropes made from whale and seal skins. Though, according to Ottar, the Saami did not practice agriculture, in the region south of Troms $\phi$, where agriculture is practicable, we find a complete Saami-dialect agricultural terminology borrowed from the Norwegians, from well before Ottar's time. While it is probably true that raising of reindeer was only done by the Saami, it would be wrong to assume that this was their only activity.

Canon Adam of Bremen, after a visit to the court of King Svein Estridson of Denmark between 1073 and 1076 wrote a Descriptio Insularum Aquilonis (republished in 1846 by B.H. Pertz). A chapter in his book concerns the "Skritefini" who, he claims, moved faster than wild animals.

The Historia Norwegiae (1180-1190) undoubtedly written by a Scandinavian, was discovered in Scotland about 1840 by P.A. Munch. ${ }^{1}$ It comprises some pages on Saami customs, describing them as nomads living in birchbark tents, (tugurea corticea), the families moving from place to place on reindeer or skis, and as subjects of the Kings: of Norway. The text ends with what is unquestionably the oldest explicit account of a remarkable shaman séance, before concluding that the Saami were superior to the "Christians" at fishing.

Saxo Grammaticus. At the beginning of the twelfth century, 
the Danish monk Saxo Grammaticus in his Gesta Danorum (1514; see also Müller, 1839) echoed the doubts as to the faith ${ }^{2}$ of the Saami kings and spoke of Finnmark as an independent kingdom which, after being defeated by a Swedish chieftain, had to pay tribute to him in the form of a sleigh full of furs for each 12 subjects, Saxo Grammaticus was the first to write about the moveable dwellings (vaga domus) of the Skridfinni, and it appears that he was also the first to name their country Lappia, ${ }^{3}$ a term which has been applied to it in literature ever since, in spite of the objections of the Saami who have never liked the name.

The Sagas of the Kings by Snorri Sturluson (1970) offer some enlightenment on contacts between the Vikings and the Saami. These sagas, written in the thirteenth century, relate events going back to the tenth and eleventh centuries. Thus we learn that one Christmas Eve at Hadeland, at least $50 \mathrm{~km}$ north of Oslo, after the table had been cleared, King Halvdan ordered a Saami to be seized and tortured to make him confess the secrets of sorcery, but with no result. The Saami, having fled with the son of the king, Harald Haarfager, later informed him of the death of his father and instructed him to do his duty and return to rule his kingdom and the rest of Norway. In the saga of Harald Haarfager it is said that Eric found a beautiful woman in the hut in Finnmark, who had come there from her home in Helgeland to learn witchcraft from two Saami.

The Saami were then exposed to the first attempts at Christianization: $\emptyset$ yvind refused to be converted because he believed that he was a "spirit" which the Saami had embodied in human form to break the spell of his parents' sterility (Olav Trygvessons s. , para 76). St. Olav himself had to fight against bad weather brought about by Saami magic (Olav den helliges s. , para 9). There are also many sagas which mention Viking expeditions ( innferd) of trade, pillage, or tax imposition to the Saami regions, e.g., the expedition of Hårek, an influential man from Hålogaland (Olav den helliges s. 6:104), and that of Tore Hund, who travelled for two winters and brought back, among other things, jackets made from reindeer skins which Saami magic had made more invincible than breastplates. The Saga of Inge (para. 6) cites the Saami supremacy in boatbuilding, though the origins of this art seem to lie within the Scandinavian domain, when Sigurd Slembe, the Pretender to the Norwegian Crown, who had taken refuge at Hinnoya, called upon Saami skill to build a boat for 24 oarsmen, to be sewn with animal sinews, made without nails, and unbeatable for speed. These Saami builders must have been more or less integrated into the Norwegian culture and must be distinguished from those who practiced magic. That practice continued for a long time, and to such an extent that the numerous "Christian" laws of the period ${ }^{4}$ even allowed for the seizure of goods from those who made voyages with the express intention of seeking Saami prophecies.

The law-enforcement and judicial systems of this period are only now in the process of being examined and explained often in response to the demands of the Saami themselves.

Much additional information can be gleaned from peace treaties and ordinances such as that of Tjälje (1323). This is a Swedish document, written in Latin, with the objective of smoothing over the problems brought about by the Swedish colonization after the Peace of Nöteborg. It used the term "Lapps": "s "homines silvestres et vagos vulgariter dictos lappa"; and stated that no one had the right to trouble them any more than the Birkarls who traded with them.

Cartographers and geographers should also be borne in mind as a source of information. Among them should be mentioned Claudius Clavus or Nicolaus Niger, whose map of the north 6 - attached to a Latin manuscript by Ptolemy, improved at the request of the French Cardinal G. Filiastrus, and finished in 1427 (Storm, 1889:125ff., 1891:43ff.) - mentions the "wildloppeland". Also in 1427, Behaim produced his globe. Somewhat later Ziegler (1532) published his Schondia, containing a map of the north ${ }^{7}$ produced with the help of oral accounts provided at a meeting in Rome with four Scandinavians, among whom were the last Catholic Archbishop of Trondheim, Eric Walkendorf, ${ }^{8}$ and the last Catholic Bishop of Uppsala, Johannes Magnus, who gave Ziegler his notes on the Schondia. 9

The latter's brother Olaus Magnus (Gothus Lincopensis, as he called himself; 1488-1557), who was with Johannes for the Council of 1538 in Venice, had also travelled in Sweden and probably Norway. During visits to Dutch and German ports, he had gathered information on the northerly regions where he had never been himself. Both Olaus and Johannes Magnus were guests of the Patriarch Hieronymus Quirirus, and it was there that Olaus was inspired to bring out his celebrated map of the Nordic regions, the "Carta Marina", in 1539. 10 (This map, published in Venice, was found in 1886 at the National Library in Munich by Dr. $O$. Brenner and should not be confused with the smaller maps such as the one in the Basle.edition of 1567 in Historia de gentibus septentrionalibus.) The "Carta Marina", drawn ostensibly for religious reasons (to depict the regions which had just left the Catholic Church), was also, in the eyes of its author, for the benefit of science, for he attempted to improve the maps based on Ptolemy's cosmology. The "Lappia" and "Scricfinnia", the "Biarmia" and the "Botnia" are all placed well up north, together with three illustrations of ethnographic interest (Fig. 1).

In 1555, O. Magnus published, in Rome, his Historia de gentibus septentrionibus comprising 22 books and 778 chapters, of which 465 are illustrated with wood engravings. Magnus speaks of the Saami in several places, mixing his own observations (for he had met some of them himself in 1515; see Magnus, 1555:II,IV) with the contemporary fantasies and prejudices inherited from his predecessors. The ethnographer can find much of interest here. Skis and ski-poles (planis lignis and bacalum) are fully described, as are the reindeer skins that were fixed on the skis to prevent their slipping back when going uphill. The illustrations show an ancient Saami tradition: the right ski - called savek except when it was covered with a skin (golos) - was shorter than the left ski, which was stronger and had a grooved inner surface to support the weight of the skier (Magnus, 1555:I,4). The ski-pole was very long and had a pointed tip like that of the bear spears (Fig. 2).

$O$. Magnus also traced in his work the geographical spread of the Scricfinni and Lappones who were, in fact, one and the 


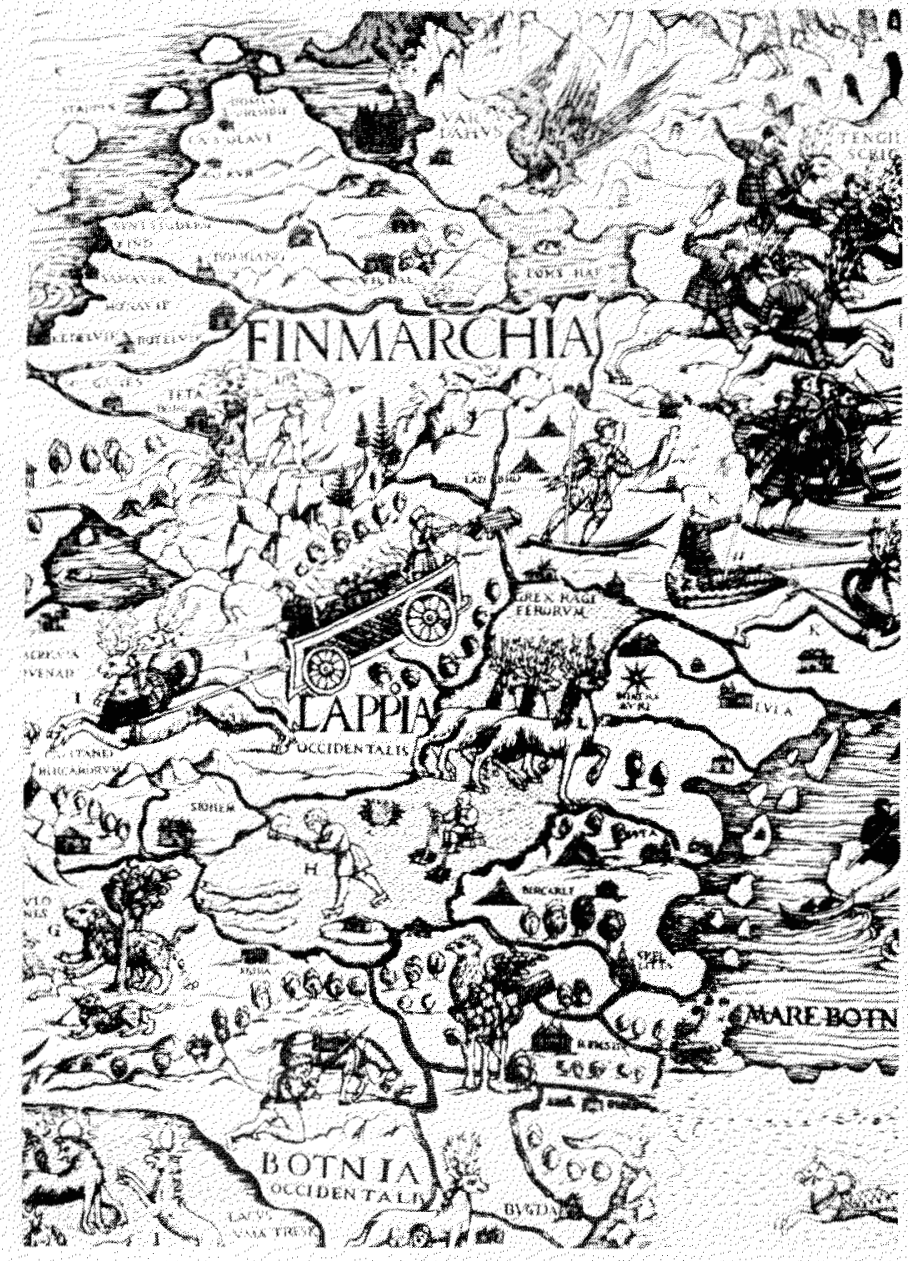

FIG. I. Finnmark, from the "Carta Marina"' of Olaus Magnus (1539).

same. He determined their areas of habitation and their way of life. He studied their market sites, their economy, and, in particular, their bartering systems with the trading cum taxgathering Birkarls. He noted the importance of hunting and fishing and all the benefits gained from reindeer (e.g., food, transport, and clothing) (Magnus, 1555:IV,3,4,5,11; XI,37; XVII, 26-30). Nor did he neglect their beliefs. On the occasion of a marriage, for example, the parents of the couple celebrated the union of their children by striking two stones together to produce sparks of fire, symbolizing the life within each sex (also see Ziegler, 1532:16-17). According to Magnus, the Saami mainly worshipped the sun, the moon, and - probably because of its antler-like mandibles - the stagbeetle (...veluti apud Aegyptos, scarebei...). He described certain rituals in which a white reindeer, or the bones of forest animals, whales, or fish, was sacrificed to the sun. A piece of red tissue fixed to a rod was reputed to possess divine force, being analogous to the animal blood which they smeared on their sacred images to increase their effectiveness. Magnus was also acquainted with the ecstatic powers of their sorcerers, which made them appear dead during their trances. When they awoke they could relate where they had been by showing a ring, a knife, or another object which they had obtained during their "journey".

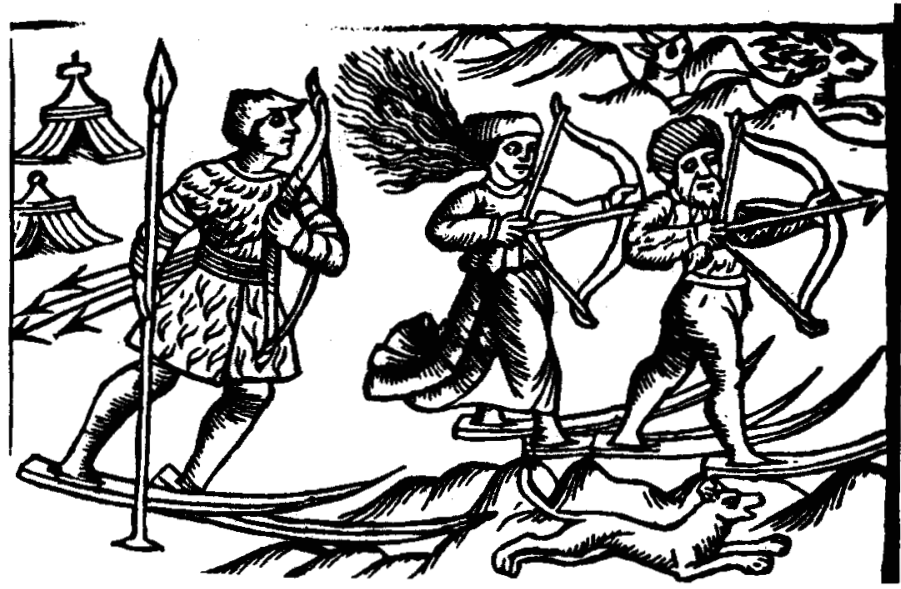

FIG. 2. Saami woman and her husband hunting on skis. From the Historia of Olaus Magnus (1555).

Magnus also referred to the magic wand of the Saami (jacula magica), later better known under the name gand, which had the power to cause illness or even death. Even today this wand is sometimes held responsible for some sharp and sudden pains. Finally, he described, as had Ziegler before him, the Saami's power to harness the winds at sea by means of three knots (Magnus, 1555:II,16). By undoing the first knot they released a favourable wind, untying the second released a stronger wind, and the third released an outright tempest.

During their lifetime, Olaus Magnus and his brother also became friends with a Portuguese knight, Damianus a Goes, whom they met in Danzig. The latter, a papal delegate, wrote a letter to the Pope deploring the paganism of the Saami, ${ }^{11}$ a paganism he delighted all the more in blackening because the religious influence in these regions was in the hands of the Reformed Church. He added to his report a description of Lappland ("Lappiae Descriptio"), probably gleaned from O. Magnus, and mentions St. Andrew's Chapel in the region of Torneå, a chapel which must have been in northern Sweden since 1345, as he says that Archbishop Hemming Laurenti went there to baptize the Saami and Fins. Further information of the same period, particularly concerning Saami beliefs about ghosts and the dead, can be found in Peucerus (1560).

Peder Clausson Friis (1545-1614), a pastor who obtained most of his information from the Helgeland judge Jon Simonsson (1512-1575), also dwells on the wild and idolatrous nature of the pagan sorcerers in his account of Norway (Friis, 1613, 1692; Storm, 1881). According to Friis, nothing could prevent their banging their magic drums in the tundra or renouncing the Christian baptism of their children to give them back their Saami names. He notes that, as well as the half-nomadic coastal Saami of the period, there had formed a group of more settled sea-going Saami who were culturally closer to the Norwegian colonizers (Fig. 3). This was also remarked upon by J.S. Stephanius (1629).

Among the travellers drawn to Lappland by their faith was a Catholic priest from Norrköping, Johan Ferdinand Körningh (1626-1687). After studying in Prague and Rome, he worked as a priest in the Order of Jesuits from 1660 onwards. At Torneå, Finland, en route to his stay in Lappland, he met 


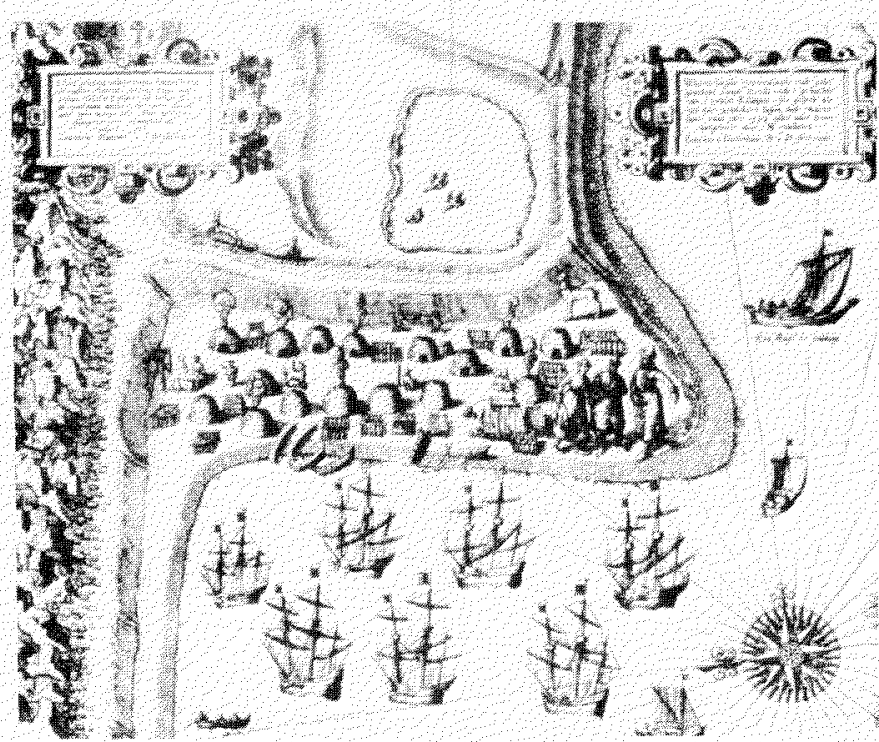

FIG. 3. Map of Kildin Island (Kola): Saami huts and reindeer with sledge. From Van Linschoten (1594-95).

Johannes Tornaeus, the senior minister of Lappmark, from whom he obtained most of his information. Father Körningh managed to persuade a Saami father to entrust to him his 13-year-old son, who was to be educated by the Jesuits in Prague with a view to preparing him as a Catholic priest for the region. He was also very interested in Saami medical remedies, some of which he took back to Prague and used, according to his obituary notice.

Father Körningh's work was a prelimináry report intended to be of use to his colleagues in the event of the re-establishment of Catholicism in the area. It touches on the geography, the fauna, the people and their customs, linguistic elements and local medicines ("Medeci sunt lappones excellentissimi") (Körningh, 1956[1660]:55-56).

The physical anthropology of this period has been addressed by Conring (1606-1681), who put forward a theory - later taken up by Schefferus - that both the Saami and the Samoyeds originated from Asia (Conring, 1665).

The Speculum Boreale (Lilienskiold, 1942[1698]) written in 1698 by the chief administrator of Vads 6 , Hans Lilienskiold (ca. 1650-1703), gives first-hand information on the state of the Finnmark population at the end of the seventeenth century. Included are descriptions of different methods of hunting reindeer and other animals; of the semi-nomadic Saami seasonal round of fishing in spring and summer and hunting in winter; of the decrease in numbers of wild reindeer and its consequences - the domestication of reindeer (Fig. 4) in the old Saami communities and the development of distinct social groups based on different resources; of the conflicts brought about by the different interests of the mountain and coastal Saami. Lilienskiold also reported on the "finneby", the equivalent of the "sii' $d a$ ": the social, political, and domestic organization of the Saami. From his descriptions it is possible to deduce how Saami society functioned internally. He analyzed the influences of the Finnish introduction of agriculture to Finnmark, and noted the rival claims of royalty to Saami

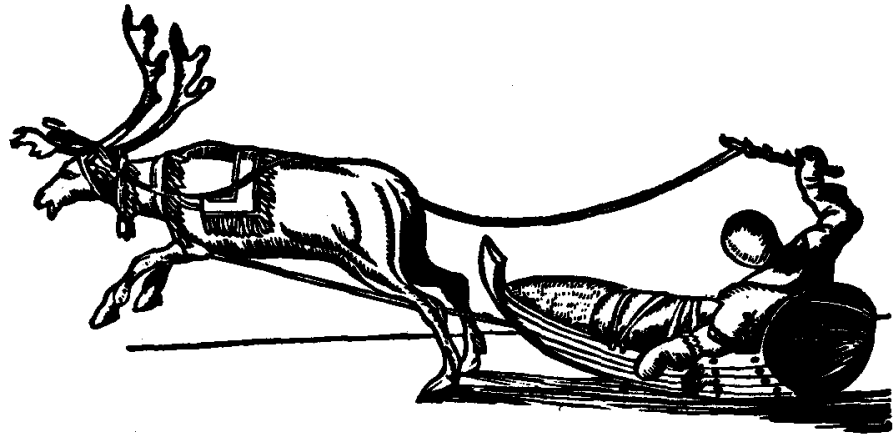

FIG. 4. Saami reindeer sledge. From J. Schefferus (1673).

lands in the guise of Swedish and Danish-Norwegian evangelical missions. He recorded many sacrificial sites and described at length a Saami shaman drum, and was interested in Saami wedding and burial customs. Lilienskiold's knowledge of Saami social organization and religious beliefs was based on the "justits-protokoller", i.e., the registers of the lawsuits in which Saami were involved. This suggests an area for study and interpretation which has been little touched upon, but which could reveal many interesting facts on the life-style of the Saami and the way they were caught up in a system of thought which, in a judicial sense, was alien to them.

Along similar lines, the administrator Niels Knag (1938 [1694]) provided a wealth of local detail about Saami life along the Varanger coast. For example, he wrote in 1694 that they paid an annual tax of nine live reindeer to the local administrator for the right to erect a barrier across an isthmus to enable them to capture the reindeer. Adelaer (1938[1690]) drew attention to the complaints made by the sea-going Saami against encroachments on their lands (Alta, Bondøya, and Lebesby) by the mountain-dwelling Saami. The herds of the latter came in summer to graze on the hunting and pasture lands of the coastal Saami, thereby destroying the basis of their economic system and creating problems for their nomadic way of life, tied to the reindeer.

The pastor and poet Petter Dass (1647-1708) included a chapter in his book (Erichsen, 1907:72-73) devoted to the "Lappene og Finnerne", in which, among other things, he recounted the magical powers of the Saami that enabled them to seek out robbers and bewitch them, using in particular the gand or "Devil's scourge".

The work of Schefferus (1673) ${ }^{12}$ marks a turning point in the history of the discovery of the Saami by its abundance of information and concern for accuracy. It was written at the request of the Count de la Gardie, Lord Chancellor of Sweden, who felt the need for a complete work of reference on this people. The Swedes were coming into more frequent contact with Saami, due to their increasing agricultural, mineral, administrative, and missionary activities in the process of colonization. Not only did Schefferus correct the errors of his predecessors, he also asked to be sent the written reports of the many ministers in Lappland: these reports dealt with both the spiritual state of the population to be converted and their general culture. Schefferus' treatise has become a classic 
among ethnological monographs. He reviews everything about the Saami in their natural environment from their religion and secret magic, their language and their techniques of attainment and consumption, their domestic and social life, to their sparetime activities and amusements. The work is too well known to be dwelt upon but it might be useful to recall some of the men whose work contributed to the compilation. The majority of these sources are concerned, naturally, with Swedish Lappland. Most of the information has been gathered together and published in the "Archives des tradition populaires suédoises". ${ }^{13}$

The pastor Petri Niurenius (1580-1645), who was established in the region of Umeå, was among the informants. He left a description of Lappland (Niurenius, 1905) which was completed by his son Ericus Plantinus. His other son, Zacharias Plantinus, added a small glossary ${ }^{14}$ and published a Saami catechism translated by Nicolaus Andreae, the pastor of Pitea, who wrote the first book published (in 1619) in the Saami language, a collection of religious chants.

However, the main source of information for Schefferus was undoubtedly Johannes Tornaeus (?-1681), who lived in the Tornea and Kemi region. Encouraged by Gustave Soop, he published in about 1653 a Lapponiae et Lapporum Descriptio, also published under the title of Narratiumcula de Lapponibus, the outline of a work to which he added later (Tornaeus, 1900[ca. 1653]). This pastor is known to have written a Manuale Lapponicum in 1648, in which the Gospels and Epistles and some passages from the Old Testament were translated into the dialect of Tornea.

The pastor Nicolaus Lundius (ca. 1650-ca. 1726), son of the first Saami pastor, supplied information (Lundius, 1905 [1674]) on the Umeå region. It was in 1674 while he was a student at Uppsala ${ }^{15}$ that he was asked to write up his notes; Schefferus knew about them, but clearly could not have used them in his first edition of 1673 .

In 1671 Samuel Rheen (?-1680) wrote his Relation (Rheen, 1897[1671]). His work is mainly about the area of Lulea and Jokkmokk where he was pastor. Although the work of another Saami pastor, Olaus Stephani Graan (1618-1690), was finished in 1672 for Magnus Gabriel de la Gardie, it also was too late for Schefferus' first edition, which was already at press. His work (Graan, 1899[1672]) gave details of the Pitea area; he followed this with an alphabet and a translation of a short catechism of Luther (1667). These are among the first literary works in the Saami language and for this reason are a goldmine for linguists.

Finally, another Swedish Saami minister, Gabriel Tuderus (1638-1707), should be mentioned for the Swedish/Finnish frontier region of Kemi (Tuderus, 1910a[1672-1679], 1910b [1685-1686]). He was known for his zeal in trying to banish Saami idolatry and sorcery. We know that he burned the magic drums whenever he found them and that he did not hesitate to seal up the sacred entry to the Saami tents (boašso). He also presided over a "Kåtakärreg", the local form of justice, derived from the ancient judicial functions of the sii'da, the Saami district or community.

Whereas in the seventeenth century Sweden took the lead in converting the Saami people, serving as a model for Norway, the situation was reversed in the eighteenth century; it was then Norwegians who took the initiative and provided the sources of reference. This change can be attributed to the Missionary College and its most striking figure, Thomas von Westen (Hammond, 1787;16 Eskeland, 1923; Saeter, 1926; Steen, 1954), nicknamed "the apostle to the Lapps", who was the leading spirit of the College from 1716 until his death in 1727 (Fig. 5). Born in 1682 at Trondheim, leader of a pietist movement, the Pleiades, this pastor was completely dedicated to the Seminarium Scholasticum, whose purpose was to train ministers for Lappland. He considered it of paramount importance that the conversion and teaching of the Saami should be in their own tongue, so - at his own expense - he opened the Seminarium Domesticum, where young Saami teachers were trained before going back to their regions to assist the missionaries there.

Von Westen made three journeys - in 1716, 1718-19 and 1723 - to Finnmark and Nord-Troms, as well as trips to Trondelag and Nordland. During his second visit he collected about 70 magic drums, which he sent to the Missionary College in Copenhagen where, unfortunately, they were burned in the Waisenhuset fire of 1728 .

While intensely eager to spread his religious beliefs to the Saami, von Westen was not blind to the fact that his work could be hindered by the bad examples set by the Scandinavian colonizers. At first, therefore, he tried to rid the Saami of habits that were harmful to them. In particular, he repurchased lands the Saami had sold for alcohol and returned them to the Saami. The pastors in Saami regions were instructed to forbid the sale of alcohol, and he tried to cut off this trade from Trondheim. Although he did not find the time to write the history of his mission, which he had promised to the King of Denmark and to the College, he left a certain number of manuscripts (von Westen, 1826[1717], 1773[1723], 1934a[1717], $1934 \mathrm{~b}[1717])$, and he had the great gift of gathering around him and leaving behind a band of colleagues whose work is worth mentioning.

One of these was Isac Olsen (1680-1730), who began his career as a teacher in Finnmark and acted as an informant on Saami paganism at Vadsd to the pastor Ludvig Christian Paus ${ }^{17}$ (1672-1742). Apparently the Saami even threatened him for revealing their religious secrets. After having met Thomas von Westen during the course of the latter's journey to Finnmark in 1716, Olsen followed him to Trondheim. There, he translated the catechism and prayers into Saami and acted as reader in this language to future missionaries, among whom was Knut Leem, known for his expert work on the Saami (Leem, 1767, 1768), although the date of his work lies outside the range of this paper. As the title of his work (Olsen, $1910^{18}$ ) indicates, Olsen was interested mainly in the theology and religious practices of the Saami of his time.

Johan Randulf, another pastor, wrote his Manuscrit de Naerd in 1723. He lived at Naer from 1718-1727. The information for his Relation (Randulf, 1903[1723]) on Saami paganism came either from his personal experience among the Saami, from Thomas von Westen, who stayed with Randulf 


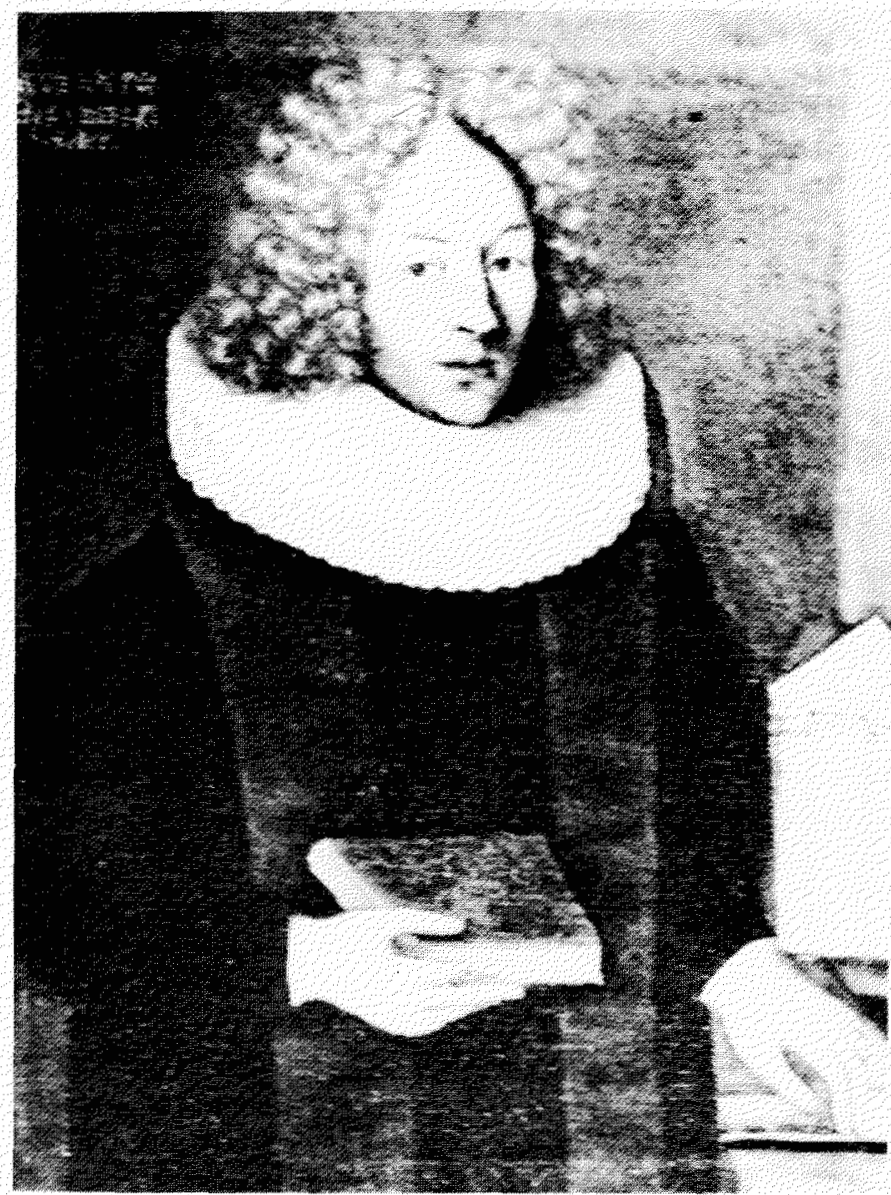

FiG. 5. Thomas von Westen $(1682-1727)$. Portrait made in 1715.

during his third visit in January 1723, or from von Westen's pupil Jens Kildal (in Reuterskiöld, 1910), a missionary in Saltem since 1721, who had married a Saami woman, Karen Arnesdotter.

The work of the Missions was examined by a contemporary, Hans Skanke (1679-1739), who gathered together the papers and manuscripts of Thomas von Westen when he died. He used these, between 1728-1731, as the basis for his Epitomes (Skanke, 1943[1731]) to which he added an explanation of all the Saami words he had used up to 1731 .

In his collection on the sources of Saami mythology, Reuterskiöld (1910) also quotes a number of texts from Norwegian and Swedish missionaries who were contemporaries of Thomas von Westen, which complete the investigations that von Westen had initiated. For example, the Relation of Carl Solander (1699-1760) is included. This text (Solander, 1910 [1727]), dealing with the Pitea region, was instigated by the journey of information and coordination made in Swedish Lappland in $1725-26$ by Jens Kildal, acting on instructions given by von Westen. (A further purpose of Kildal's visit was to prevent the Swedish Saami, who were less Christianized, from giving a bad example to the Norwegian Saami during their summer travels to Norway, and to ensure that the Norwegian Saami were not without spiritual advisors when they, in their turn, went into Swedish Lappland. Kildal, known for his bigoted intolerance, went so far as to threaten the Swedish Saami with expulsion from Norway and the killing of their reindeer because their behaviour was not up to his standards). Jens Kildal played the same instigating role with Forbus (in Reuterskiöld, 1910), minister of Neder Torneå, and with Lennart Sidenius (in Reuterskiöld, 1910), pastor of Jamtland. Sidenius collaborated with Simon Kildal, Jens's brother, to improve Forbus's report (in Reuterskiöld, 1910).

A great deal of information can be drawn from all the authors mentioned so far, but a critical and detailed examination of the minutiae of the reports is not the purpose of this paper. The purpose is rather to give a broad outline of the ethnological conclusions which can be drawn from these sources for the period under investigation.

At the beginning of the Middle Ages the Saami were essentially a hunting, fishing, and foraging people (Fig. 6). They kept a few domestic reindeer as draught animals and as lures for wild reindeer hunting. Their way of life was closely linked with the ecology of the Arctic, which imposed on them a seasonal semi-nomadism enabling them to exploit all the available resources of nature. These resources went far beyond the livelihood based solely on the reindeer to which the Saami have been too often relegated. ${ }^{19}$

In the eighteenth century there arose a distinct territorial and economic differentiation, partly a natural consequence of the pressure of colonization, which influenced the structure of the Saami sub-cultures. At the same time fiscal demands and the rule of royal administrators and missionaries disrupted the traditional social systems and tried to diminish and absorb them.

It is interesting to examine how these social systems worked, through the authority of the "sii'da" or "sit" (depending on eastern or western origin), native terms still in use though the sense has changed. Each head of family - or failing him, the oldest adult son or, more rarely, the widow took part in the running of the community through a deliberating council or "norraz". Each council elected, for a one-year term, a headman, leader, or president, the "oaiv'olmas" (in eastern Lappland), who was responsible for carrying out any

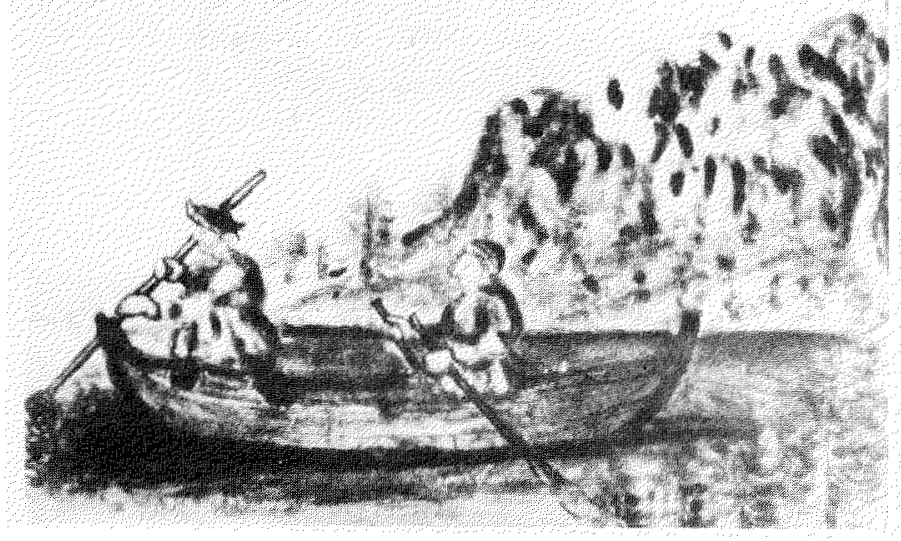

FIG. 6. Saami fishermen in a rowboat. From Lilienskiold, Speculum Boreale (1698). 
decisions taken. The length of his mandate meant that he was under the direct control of his electors. He had one or two assistants ("oaiv'olma'veakke") to help him carry out his duties, whose other function was to act as liaison between the headman and other community members, and later between him and outside authorities. This system, well known in the Kola region, where it lasted longer than in other Saami regions, was still in operation in 1691 in Finnmark where the sii'da of the sea-going Saami was under two leaders, the "finnelensmann." and his assistant the "chochstarus".

The boundaries of each sit were delimited according to the geographical lay of the land, and strengthened by users' rights over several generations. There were also areas in common, with constantly changing borders, where the absence of natural boundaries made fixed boundaries impossible. Every time a need arose for a provisional frontier, it was decided upon and controlled by two delegates from each community concerned. This meeting of two neighbouring communities, the "Kueht'mierr'norraz", was held to discuss the requisite delimitation not from the point of view of the strong rights of. each sit but in a spirit of goodwill, seeking to enlarge or diminish a sit to the real benefit of each.

Since the sii'da or sit had jurisdiction over the use of its territory, it was natural that it made regulations over the economic life of its members - based from ancient times on fishing, hunting, and reindeer breeding. The tenure of certain lands and waters had been, from the early times - at least until the modifications of colonization affected it - conceded to individuals by the collective community, which, however, remained the overall owner. The evidence for this comes from an examination of various dispositions taken by the community council over the exploitation and social and ecological regulations of hunting and fishing.

For example, reindeer hunting necessitated the participation and cooperation of a large number of people, especially the construction of "vuobman." (an angled barrier) or "aggues", (a barrier surrounded by traps or snares), and when hunting on crusty snow. Not only did the preparation for the hunt need the efforts of more than one family; the results could not be dealt with single-handedly either. The fruits of the hunt belonged to all the members of the community irrespective of whose lands were hunted. The gains of the hunt were shared out in proportion to the number of males over one year old in each participating family. All those who had been called by the organizing committee to take part had a right to a share of the profits. The only people allowed to benefit without being physically present were the old people; those without means, or people either permanently or accidentally handicapped, who were unable to provide for themselves. This recalls a judgment of the tribunal at Sompio on 26 February 1704 on a Saami man who had complained that he had not received his share from the hunt. The sii'dâ. said he had not taken part in the hunt for several years, without a valid excuse.

The hunt for bears, wolves, and other big game was organized in the same way. Over a long period, the whole sii'da cooperated and each member had his particular role to play. For example, he who located a bear's lair and gradually closed in on it had the right to call for the final kill. The bear was eaten at a general banquet with a slight religious element as the Saami, like many arctic peoples, have a special reverence for the nature of the bear. The best pieces of meat, particularly the most succulent bits from the back, went automatically to the oldest hunters present; the women, because of certain taboos, received only certain defined pieces; and after that the rest of the animal was shared out equally.

Fishing was also carried out for the benefit of the community subject to a fairly wide-ranging series of rules. Distinctions were made among fishing in lakes, running water, and the sea, and the fishing system varied according to the kind of fish caught. From all of this it is possible to deduce some idea of the Saami conception of fishing rights. Lake fishing was done on a family basis. In general, each family - that is to say (in the case of the Skolt Saami, from which most of our information comes), all the people related to the head of the family returned each autumn to their traditional fishing grounds. These grounds were not; however, their property. Male children usually inherited the use of the same grounds at their father's death, but this was only with the tacit consent of the village community and only then if there were no problems or particular objections to it. Proof exists that from time to time the traditional fishing grounds of one family were taken away and given either to another family which had become more numerous or to new arrivals.

The norraz alone had the right to order the overall transfer of the use of a territory but, in practice, each family had the right to grant the use of their grounds to another member of the community. For seine-fishing, which necessitated the use of several nets and the labour of many able-bodied men, some families grouped together within the sit to fish, but the sharing of the catch seems to have remained a family matter.

For a long time the Saami knew nothing about salmon fishing with a line, but netted the fish in the rivers. The norraz often let out the salmon stretches on the rivers and used the revenues to help pay the taxes of the members to the sii'dâ. Salmon-fishing grounds at sea were initially drawn by lot, after.which there was an annual rotation of plots among the various families until the original position was reached, whereupon there was a new draw. Nevertheless, for a long time the entire proceeds were put into a common pool and shared out between the families, not excluding the needy. The poor, old, and sick were always assisted by their own community. Many of these details lead to thoughts of an incipient form of economic communism, even if there were only a few traces left by the seventeenth and eighteenth centuries. It has been almost certainly established that individual families had the right to the use of lands and stretches of water only with the agreement of their central committee, which watched over the equitable distribution of the profits coming in. In the eighteenth century, certain hunting or fishing grounds were granted outright to an individual or a family, but the implements of fishing and hunting must initially have been collectively shared, as was the distribution.

In addition to its political and territorial powers, the sit had judicial powers. The norraz functioned as a court of justice, 
investigating and handing out judgments according to a moral code, an outline of which can be inferred from reports and judicial decisions in the Archives. There was a long list of offenses. A distinction was made between thefts committed by day and those - more serious - committed at night, and between theft in open and closed places. The stealing of fish from a net or of game from a snare outside the thief's own territory, and the receiving of stolen goods, were very severely punished: not only did the thief have to give back whatever he had stolen, but he also had to pay a fine of double the worth of the object stolen. On the other hand, the right to judge criminal offenses was taken away from the court early on. For example, in 1517 the Grand Duke of Muscovy issued a decree taking away from the Saami under Russian control the right to inflict the death sentence (which was only applied to murderers, who were normally tied to their victims and buried alive with them).

For a long time the rare sessions of the Swedish court of justice were augmented by the "Kåtakdrreg", the "tent law court", which could hand down the sentence of death by hanging. This verdict was carried out by the "sii'da-ised", the equivalent of the oaiv'olmaš. in the eastern sit.

It can be supposed that traditional life was much the same everywhere, except in areas where ecological conditions were completely different. In winter, the Saami looked after the herds of reindeer they kept for transport, and hunted. In spring they migrated to the sea, lakes, or rivers, where they fished until autumn. Then it was time to round up the herds of domestic reindeer and move on to fish in other regions and begin the hunt for furred animals. Certainly there was nothing immutably fixed about this hunting and fishing culture: the location of a group's territory - near the sea or far in the interior must have given rise to some differences, but it was only with the advent of the colonizers that marked differences made themselves felt and eventually became more rigid.

The first people to be affected were those who lived along the seacoast, where easier communications and prolonged contact with other cultures brought greater disruption. These people were known as sea-going Saami, as opposed to the mountain Saami. Their way of life was similar, though the regions they lived in were different. However, although it was natural for the sea-going Saami to place more emphasis on fishing and the mountain Saami on hunting, there was nothing to stop the former from hunting reindeer in winter or the latter from fishing along the coast in the summer.

An example of real immigration, as opposed to a seasonal establishment along the coast, occurred in Norwegian Finnmark. The Norwegians came for the fishing and were even financed by a "fishing company". Finnish refugees also arrived, fleeing the advance of the Mongol Khan Ugedei. At the beginning of the eighteenth century, the Swedish wars (1711, 1716-17, 1737-1749).added their impact to the stream of newcomers. The Norwegian immigrants mainly installed themselves on the hunting grounds of the coastal Saami; particularly along the coasts, and above all; on the islands, which gave entry to the fjords. By doing this, they gradually pushed the Saami farther and farther up the fjords, destroying their semi-nomadism. Forced to abandon their few domestic reindeer, the Saami tried to breed them, using Scandinavian methods. They also raised the art of boat-building to a high level of craftsmanship. For many years they were much better than their usurpers at whale and seal hunting and at making garments out of skins. In a sense, the colonizers were appreciably dependent on the Saami until the eighteenth century.

The small number of settlers at the beginning can be explained by the hard life and unstable conditions, but in spite of this, they were responsible for changing the Saami economy between 1650 and 1750. In an attempt to improve their standard of living, having already helped to deplete the Saami's maritime resources, they went still further and diminished their game resources by systematically hunting wild reindeer with firearms in autumn and winter. The general scarcity of reindeer which followed compelled the Saami of the interior to develop the art of breeding reindeer for purposes other than their originial uses (as beasts of burden and decoys). In doing this, they encroached on the traditional pastures of the coastal Saami in summer, resulting in conflicts between the two groups. Besides, the poorest people in both communities became sedentary and gave up breeding and hunting, just at the moment when the domesticated reindeer were taking over grazing lands intended for sheep, and the care of the few reindeer they had left was handed over to the mountain Saami. At the same time, there was a scarcity of whales and seals because of intensive hunting by the Scandinavians and the warming of the waters, so the coastal Saami withdrew to the furthest ends of the fjords, where they lived on a little fishing, a little agriculture, and animal breeding. The mountain Saami, who were forced to settle down and adopt the way of life of the coastal Saami, quickly lost the use of even their own dialect. These groups remained very poor and their lives were rough and uncertain. Reports from 1638 show their difficulties in paying their taxes in money (Fig. 7). Often they had to sell their capital, e.g., a few head of cattle or sheep. They also received very little payment for the salmon they caught. As for those who became the "princes" of their country, the breeders, it was only relatively late that domestic reindeer became their main source of income: in the last half of the sixteenth century, hunting and fishing still constituted the basis of their revenue. ${ }^{20}$ During their annual migration they followed the few reindeer they kept as a means of transport but, up to the beginning of the seventeenth century, sea fishing and hunting wild reindeer in the autumn were of prime importance.

The distinction between the Saami cattle-breeders of the mountains and those of the forests is indicated by the differences in their methods of cattle-raising, which were subject to environmental conditions. This distinction is quite independent of the theory put forward to explain the origin of the cattle-breeding. The nomadism of the mountain Saami seems to have originated in watching over the herds of wild reindeer, while the hunters and trappers of the forests exercised a stricter and more collective control of the game for its protection. The spread-out and always less-domesticated herds of the northern Saami came originally from the small herds of domesticated reindeer kept in ancient times for transport and as 


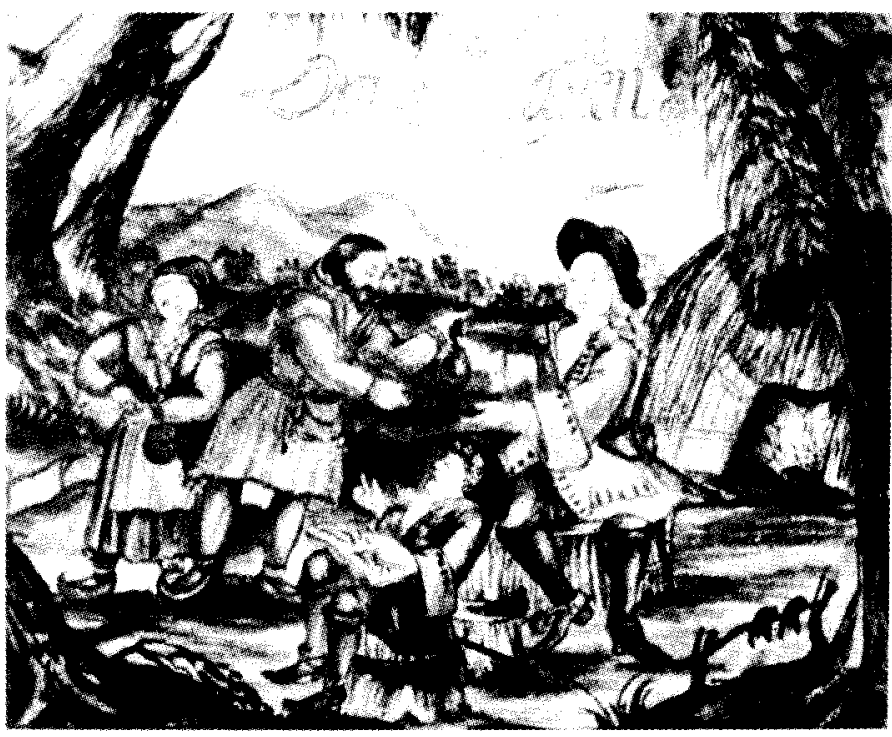

FIG, 7. Royal administrator and his secretary collecting taxes from the Saami: a source of dispute between rival states. From Lilienskiold, Speculum Boreale (1698).

decoys, and though they were relatively fewer in number they were more intensively farmed. ${ }^{21}$

Confirmation of this theory lies in the different attitudes of the mountain and forest Saami toward the stealing of reindeer. The mountain Saami had never considered this a very serious offense, an attitude which probably came from a time when the herd belonged to the community, albeit subject to certain rules. On the other hand, to the forest Saami, further south, it was a serious offense, since from the beginning the few reindeer they had were individual property.

The mixed economy of the forest Saami explains why they looked upon reindeer farming as a secondary means of support, useful in the event of a hunting failure and also as a complement to hunting, as the reindeer.were used for transport and as decoys. In some areas milk from domesticated herds was used, but these herds were always small. For example, at the beginning of the seventeenth century, the Kemi region in Finnish Lappland had about 400 reindeer, about four per family. Only in the western forest regions, where nomadic habits were more common; did the Saami have larger numbers of reindeer.

Generally speaking, the Skolt Saami and those on the Kola peninsula remained the longest close to the original culture (Figs. 8, 9) of the coastal and forest-dwelling Saami, while retaining certain characteristics of the ancient hunting and fishing culture. That they were gradually set apart from the others was partly a result of the changing frontiers, which had a greater effect here than in other Scandinavian countries. The changes were accentuated by a different kind of administration and a different religion, for Tryphon had implanted the Greek. Orthodox religion when he came to Petsjanga to expiate his past excesses. He had obtained; in 1556 and 1589 , the concession of the region for his monasteries, a grant which was only taken away in the time of Peter the Great.

Already in the seventeenth century the Saami east of Neiden (east Finnmark) were called oriental or Nuortalazzat. Thus the frontiers helped to differentiate between the Saami peoples, according to whose rule they came under. Early on; the impositions to which they were subjected were a sign of other powers' interests in the resources of the region and the determination of these powers to keep their supremacy by slowing any advance of their neighbours. This explains why it was that over a certain period the Saami owed allegiance to several kingdoms at the same time. From the ninth century, as we have seen with Ottar, the Norwegians made exploratory journeys in Lappland as far as Ter in the Kola peninsula. However, in the twelfth or thirteenth century the eastern Saami fell fairly quickly under the domination of the Novgorod merchants, until the fall of that city in 1478 after which they came under Russian control. In spite of this, up to the beginning of the fourteenth century, the Karelians were able to levy their taxes in these regions, which later became Norrbotten in Sweden, and even spread as far as the coasts of Norway from their base in the White Sea. Nevertheless, the Swedish Crown put an end to the Karelian expeditions during the thirteenth century, especially after the peace of 1323 , which determined

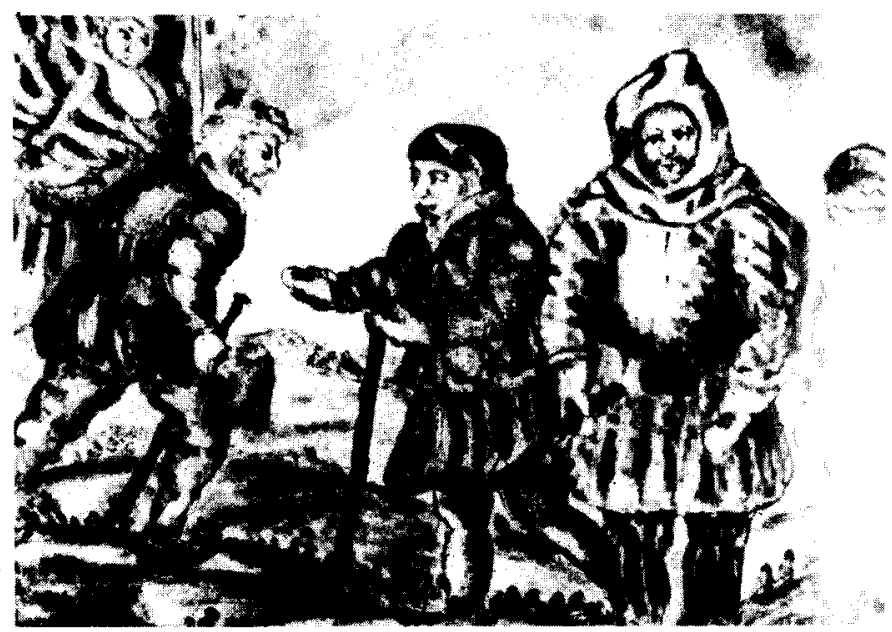

FIG : 8. Saami in winter clothing. From Lilienskiold, Speculum Bareale (1698).

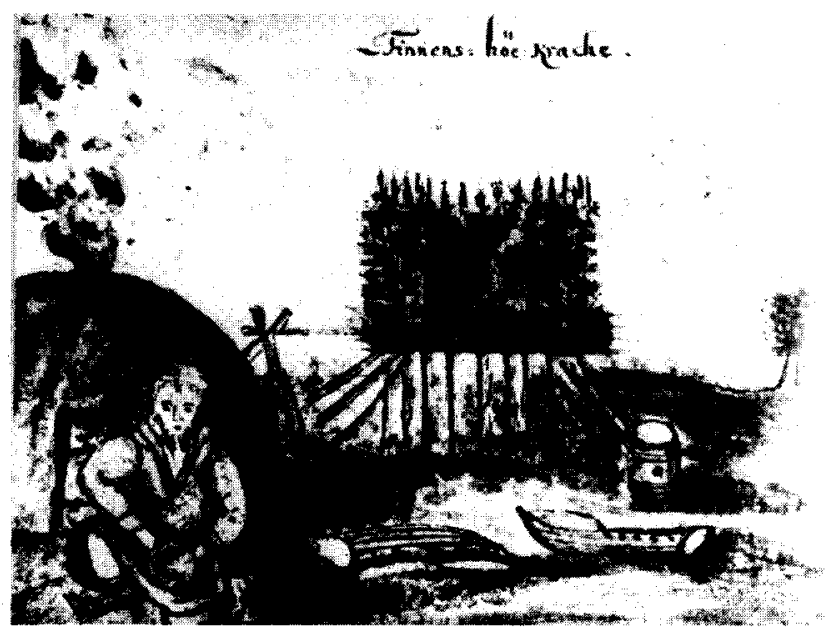

FIG. 9. Saami man outside his tent; a platform with stones, for hay storage, in background. From Lilienskiold, Speculum Boreale (1698). 
the frontier between Russia and Sweden/Finnland from the Ule. Swedish expansion only stopped at the beginning of the sixteenth century with the peace of Täysina, which fixed a new frontier little different from the actual Russian/Finnish border of today.

When the Vikings of Novgorod subdued the Karelians, the frontier was fixed between Russia and Norway at the peace of 1326, without either side giving up its mutual tax and economic claims. It remained practically unchanged until it was finally settled with the frontier laws of the nineteenth century. Thus the Kola peninsula and part of Troms were subject to a joint rule.

With the Karelians blocked, it was Finland's turn to try to make an easy fortune. In 1595, Sweden officially took possession of the Kemi region and confirmed her presence at Tornio, a zone which was strongly influenced by the Pirkkalaiset or Birkarlar, the huntsmen-traders who received tribute from the Saami. These Birkarlar extended their range of influence as far as the Saami of Varanger and of Nordland in Norway, already imposed upon by the Danish Crown. This is why, at least in Sweden - where, bit by bit, the Swedish traders came to lend a hand to the Birkarls to the extent of being assimilated by them, and in spite of royal sovereignty over the whole of Sweden - one can distinguish the Saami of the King (those from Västerbotten) from those of Kemi, Tornio, Lulea, and Piteå, who were considered the serfs of the Birkarls. With the dissolution of the Union of Kalmar in 1523, the claims of all the rival kingdoms reappeared. For example, though the King of Denmark-Norway forbade the Birkarls to levy trade taxes on the coastal Saami, Gustavus Vasa turned them into official tax gatherers for the purpose of expanding Swedish territory. One of his successors, Charles IX, however, had to give up both his pretensions to Swedish hegemony over Finnmark and his expeditions to Petsamo and Kola, following the 1611 war against Denmark-Norway (settled at the peace of Knaer $\phi d$ in 1613).

It is clear from all this that the Finnish-Scandinavian hold over this area, which had been unimportant at the time of Ottar, had become a determining factor by the time of Thomas von Westen. This was.not only because of exploitation but also because the colonization was an agent in the break-up of totally different societies, as much on the material plane - for the changed economy weakened social cohesion - as on the mental and psychological plane, In this respect, from the viewpoint of the discoverers with their preconceived ideas, the Saami were abominable pagans and sorcerers capable of corrupting the one true faith of the colonizers.

Information on Saami religious beliefs is plentiful, and especially valuable because of its antiquity compared to the more recent knowledge about other arctic areas. Thus we know that the Saami worshipped stones or pieces of wood called "seidi", a throwback to an archaic animism in which some inanimate objects were considered to harbour spirits and hence to possess supernatural powers. High mountains were often considered sacred and called "saivo". "The reason for this sacredness," according to Naerø's manuscript, "lies in their guardian angel, which helps them in each undertaking.
The Lapps choose one or two of these mountain angels as their protective spirits, which they call upon with their joik [a chant of shaman origin] whenever they do anything very important like beating a drum for soothsaying." These mountain spirits were also in mystical contact with spiritual beings in the underworld, more or less linked with the realm of the dead. Hunting and fishing depended on the position of the seidi, which influenced the region round them. So also did a series of other benefits such as health, luck, and cattle-rearing. This cult may have had its origins in the more ancient ancestorworship and reverence for the dead. Each village had its own seidi; Tornaeus (1900[ca. 1653]) mentions that each family, or an individual, could possess their own seidi. Their strength depended on sacrifices offered to them, mainly unctions of blood and grease, or gifts of wood or reindeer bone. Saami religion as depicted by the missionaries had already become a more personal faith, probably as a result of Finnish and Scandinavian pressure. Ideas about their principal gods were common to all Saami, though they were more explicit and developed in the west than in the east where outside influence was feebler. The gods of thunder, the sun, the moon, the wind, and hunting, in their closeness and familiarity, must have struck an innate chord more arctic and Saami than Scandinavian.

Shamanism and bear worship are equally well described if not interpreted - by the same authors. The worship of the bear was, on the one hand, connected to the veneration in which the Saami held most of their animals: Lundius (1905[1674]) speaks of a hunting taboo in which women were never allowed to eat the hindquarters of any animal. On the other hand, the bear was more specifically worshipped as a result of the close connection made between the bear and the spirits of the dead. The bear was after all, called saivo, sacred, a word applied to the spirits or souls of the dead; this was a reflection of the primeval belief that many animals were animal spirits, kindred to human spirits and indeed identical during a period of metamorphosis. Rheen (1897[1671]) and Randulf (1903[1723]) described particularly well the established ritual for a hunt, from the finding of a bear to the return trip and announcement of its death to the women and children in the village at the ceremonial banquet.

As already mentioned, the oldest shaman séance recorded is in the Historia Norvegiae of about 1170 , where a fight between two shamans in a trance is described. The combat takes place through the intermediary of their other spirits, a sort of alter ego, and the shaman who takes the form of a whale is disembowelled by the other in the form of a stake in the sea. The basis for this belief rests on a dual concept of reality, on the one hand corporeal and visible and on the other spiritual and invisible. The ability to leave the body at death or during a dream or, in the case of the shaman, during a trance, was a way of gaining power and knowledge. The mediatory role and effectiveness of the shaman can well be understood if one considers the main tasks which fell on him: looking for lost or stolen souls and handing them back to their rightful owners; delivering a soul possessed by an object or foreign spirit; divining the past and future; unmasking thieves and finding lost objects; and accompanying souls. He was the hunting 


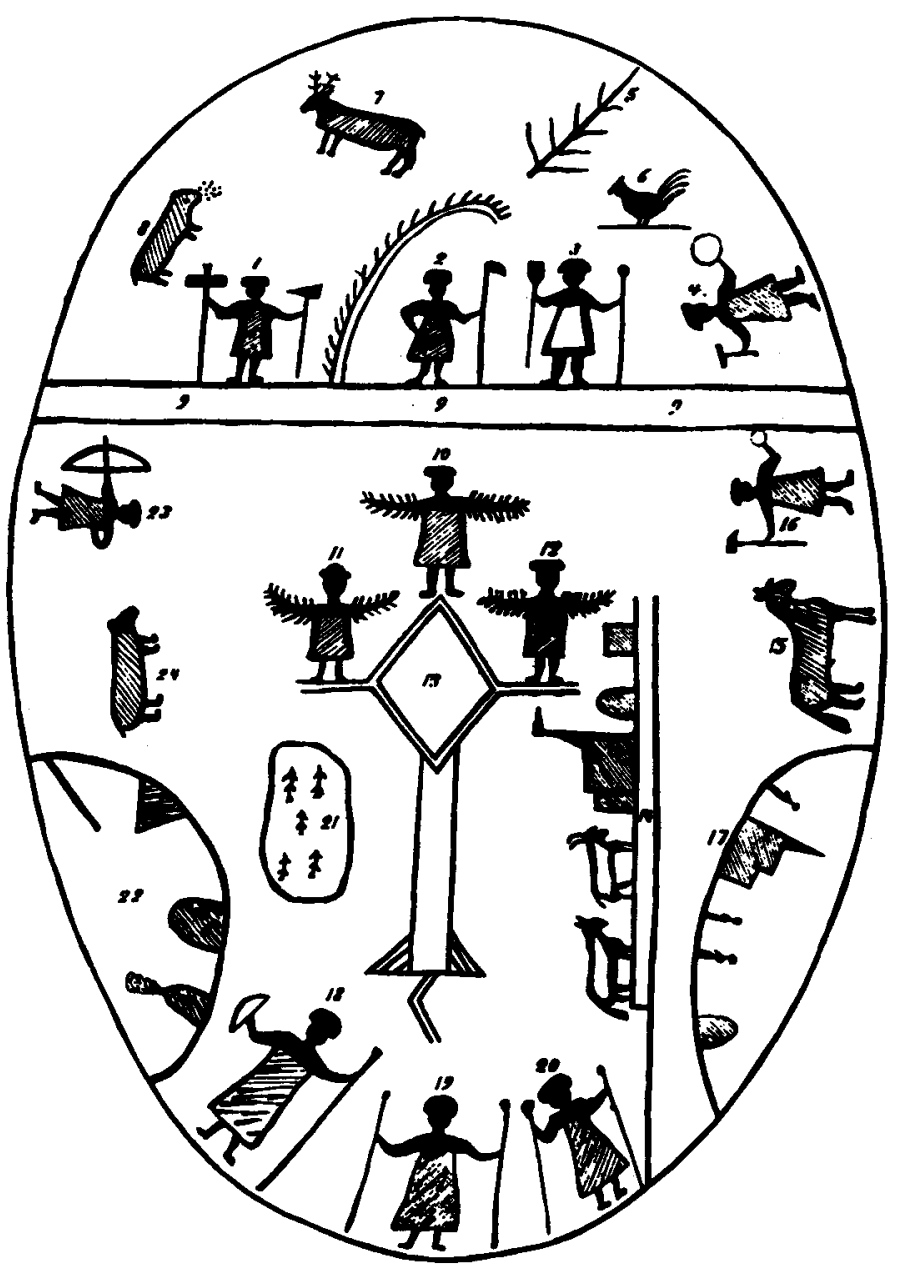

FIG. 10. Drum described in the Naerd manuscript (Randulf, 1723).

magician, the charmer of animals, and on exceptional occasions, the sacrificial priest.

We have fairly precise information about the Saami pantheon thanks to the drums used by the shamans in their trance sessions. The missionaries collected some drums and had the significance of the painted shapes on the skins (Fig. 10) explained to them. These shamans (noaide) had differing status in Saami society according to their power or specialty. With the passage of time there was a degeneration in the shaman séances and in the use of the drums, which changed from the instrument that aided the shaman's journey to, and in, another world, to simply another divining instrument.

Knowledge about the Saami world was considerably enriched from the ninth to the eighteenth centuries, and in the process this world was changed by those who explored it. The discoveries, as has been shown, were often fuelled by economic, territorial, or state interests, or by the missionaries. The task remains of sorting out the real from the imaginary facts about this epoch and region, using the inevitably biased accounts of history. While a complete sociological analysis is out of the question, we can reasonably conclude that the Saami, a small, pacific people, well adapted to their natural environment, were ground under the heel of their more populous and adventurous neighbours whenever the contact between them was close. Although such contact was often velvet-gloved, it does not alter the fact that a colonial-type situation developed very early on, forcing the indigenous people to change first their economic and then their social structure; this, in turn, led to a strengthening of their internal heterogeneity. The implantation of religion completed the dismantling of an ancient and traditional society.

Merchants, officials, and missionaries all acted in the interests of so-called higher powers, without always realizing that their methods of civilization and government were sometimes unsuited to the old Saami world. The end result was that from the middle of the eightenth century, this world started to decline and disintegrate: poverty increased, the social system and traditional beliefs weakened and disappeared, a tendency to withdraw into themselves and distrust others increased, and while lip service was paid to the new religion and socio-political structures imposed on them, the people gained nothing from them to replenish their vital resources. Only after the religious revival of Laestadius in the middle of the nineteenth century and with the struggle for an ethnic identity at the end of the twentieth century, is it possible to see these people of northern Europe for what they are and would like to become. To acknowledge their aspirations for national identity requires more than a simple change of words and calling them by the indigenous word they themselves prefer to be known by: "Saami".

\section{NOTES}

'Republished by Storm: Monumenta Historica Norvegiae (Kristiania, 1880). The two last tracts are in "Den eldste Noregs-historia", translated from the Latin by $\mathrm{H}$. Koht, and the supplement "Meldingane fra Noreg"' by Adam of Bremen, in Det norske samlaget (Oslo, 1921).

${ }^{2}$ The origins of the Saami faith go back to the $E d d a$, where it is said that Volund and his brothers were descendants of a Saami chief (finnakonungr).

${ }^{3} \mathrm{~A}$ word which can doubtless be linked to the Finnish lappi, meaning "northern wastes". A papal missive to the Archbishop of Uppsala, dated 9 January 1230, contains the information that the enemies of the Church, the pagans, lived in Lappia. The name of the actual inhabitants is not mentioned.

"Particularly the "Borgartingalov" ruling the region of Vik, the "Eidsivatingslov" for the central region between Värmland and Hedemark, and the "Dovre", drawn up between 1067 and 1120 . The "Frostatingslov" for Trondelag and Hålogaland dates from 1260.

'The term probably follows from Saxo Grammaticus, whose name "Lappia" for the country came to be applied to the inhabitants. Claudius Clavus termed them "Wildlappmanni", and Martin Behaim called them "wild lapen". The term can also be found in the Fundinn Noregr, written at the same period.

${ }^{6} \mathrm{~A}$ facsimile can be found in Nordenskiöld (1883-84:55) and also in Storm (1891).

'Reproduced in Nordenskiöld, Voyage autour de l'Asie et de l'Europe, I.

${ }^{8}$ Walkendorf was the author of Breuis et summaria descriptio Nidorensis diocesis et specialiter cuisdam ipsius partis que Findmarkia dicitur, externa aquilamaris Christianitatis plaga, published with a Norwegian translation by Karlsson and Storm (1902-12).

"These notes were published under the title "Situs Scandia" as a foreword to the work he wrote later, Historia de omnibus Gothorum 
Sueonumque regibus (Rome, 1554); a Swedish translation, Swea och Götha Kronika, was published in Stockholm in 1620.

${ }^{10} \mathrm{~A}$ facsimile can be found in Brenner (1886).

"1"Deploratio Lappianae gentis \& Lappiae Descriptio". Lovanii, 1540 et Coloniae, 1573 et 1602 . A Swedish translation was made by Gösta Thörnell (1915).

${ }^{12}$ See also the enlarged French translation, Histoire de la Laponie (Paris, 1678).

${ }^{13}$ Bidrag till Kännedom om de Svenska Landsmålen och Svenskt Folkeliv. Vol. XVII, 1897-1907.

${ }^{14}$ Published in the Journal de la Société finno-ougrienne VIII. Praefatiumcula Praemisso lexico lapponico. Helsingfors, 1890.

${ }^{15}$ Like Olaus Mathias, another Saami informant, who also was a student at Uppsala.

${ }^{16}$ Hans Hammond was the son of the pastor Thomas Hammond, who was the son-in-law of Anna Persdatter, the last wife of Thomas von Westen.

${ }^{17} \mathrm{Cf}$. "Relation om Lappernes afguderier og vildfarelser 1715," Vads 12/3/1715. MS at the Kgl. Bibliot., Copenhagen (5 no. 227). ${ }^{18} \mathrm{Cf}$. also "Finnernis Afgudssteder", Nordnorske Samlinger I (Oslo, 1934).

${ }^{19}$ For example, up to the seventeenth century the Saami of Kautokeino, today a reindeer-breeding centre, paid their taxes in dried sea fish, pike, and salmon.

${ }^{20}$ If one can trust the legends, accounts of magical techniques, and an analysis of the drawings of drums, reindeer breeding did not occupy a place of any great importance, nor was it one of the principal preoccupations of the Saami.

${ }^{21}$ The domestication skills of the southern Saami were such that they used only sticks, not lassoos, to separate the herds.

\section{REFERENCES}

ADELAER, H. 1938 [1690]. Henrich Adelaer i Finnmark 1690. Nordnorske Samlinger I. Oslo: Etnografisk Museum.

BOSWORTH, J. 1855. Description of Europa and the voyage of Othere and Wulfstan by King Alfred the Great. London.

BRENNER, O. 1886. Die achte Karte des Olaus Magnus Vom Jahre 1539. Kristiania: Videnskabs Salskabs Forhandlinger No. 15.

CONRING. 1665. De Antiquissimo statu Helmestadii et vicinae conjecturae. Helmestadii.

ERICHSEN, A.E. (ed.). 1907. Dass, P. Nordlands Trompet eller Beskribelse over Nordlans Amt. Kristiania: Folkeudgave.

ESKELAND, 1923. Thomas von Westen. Bergen.

FRIIS, P.C. 1613, 1692. Norriges et omliggen de ders sanfairdige Bescrieffuelse. Copenhagen.

GRAAN, O.S. 1899 [1672]. Relation, Eller En Fulkomblig Beskrifning om Lapparnas Versprung, sa wähl som om Leela dheras Lefwernes Förehallande. Bidrag till Kännedom om de Svenska Landsmålen och Svenskt Folkeliv XVII (2). Uppsala.

GRAMMATICUS, S. 1514. Gesta Danorum. 16 vols. Roskilde.

HAMMOND, H. 1787. Den Nordiske Missions - Historia i Nordiandene Finnmarken og Trundheims Amt. Copenhagen.

KARLSSON, H. and STORM, G. 1902. Det Norske geograf. Selsk, Aarbog, Kristiania.

KILDAL, J. 1910. Appendix till hans verk: Afguderiets Dempelse. In: Reuterskiöld, E. Källskrifter till Lappernas mytologi. Stockholm.

KNAG, N. 1938 [1694]. Matricul oc veschrifuelse ofver Findmarcher for Anno 1694. Nordnorske Samlinger I(1). Oslo: Etnografisk Museum.

KÖRNINGH, J.F. 1956 [1660]. Barättelse om en missionresa till Lappland 1659-60. Latin text translated by Granlund, J. Acta Lapponica IX(1). Uppsala: Nordiska Museet.

LEEM, K. 1767. Beskrivelse over Finmarken Lapper, deres Tungemaal Levermaade og forrige Afgusdyrkelse. Copenhagen.

1768. Lexicon Lapponicum Bipartitum, Lapponico-DanicoLatinum et Danico-Latino-Lapponicum. 1-2. Hafniae 1768-1781.
LILIENSKIOLD, H. 1942 [1698]. Speculum Boreale. Nordnorske Samlinger 4. Oslo: Etnografisk Museum.

LUNDIUS, N. 1905 [1674]. Descriptio Lapponiae. Bidrag till Kännedom om de Svenska Landsmålen och Svenskt Folkeliv XVII(5). Uppsala.

MAGNUS, O. 1555. Historia de gentibus septentrionalibus. 22 vols. Rome.

MÜLLER, P.E. (ed.). 1839. Historia Danica. Havn.

NIURENIUS, O.P. 1905. Lappland eller beskrivning ofver den nordiska trakt som lapparne bebo i avlägsnaste delarne av Skandien eller Sverige. Bidrag till Kännedom om de Svenska Landsmålen och Svenskt Folkeliv. XVII(4). Uppsala.

NORDENSKIÖLD, H. 1883-84. Facsimileatlas. Stockholm: Studier och forskmingar.

OLSEN, I. 1910. Om Lappernes vildfarelser og overtro. Kildeskrifter til den lappiske Mythologi II. Det kgl, Norske Vidensk. Selsk. Skrifter no. 4. Trondheim.

PEUCERUS, C. 1560 . Commentarius de praecipiis divinationum generibus. Watebergae.

RANDULF, J. 1903 [1723]. Relation onlangende Find-Lappernis, saavel i Nordlandene og Findmarken som udi Nummedalen, Snaasen og Sedboe. Kildeskrifter til den lappiske Mythologi, no. 1. Trondheim.

RHEEN, S. 1897 [1671]. En kortt Relation om Lapparnes Lefwarne och Sedher, wijd-Skiepelser, sampt i manga Stycken Grofwe wildfarellsser. Bidrag till Kännedom om de Svenskae Landsmålen och Svenskt Folkeliv. Uppsala.

REUTERSKIÖLD, E. 1910. Källskrifter till Lappernas mytologi. Stockholm.

SCHEFFERUS, J. 1673. Lapponia. Frankfort.

SKANKE, H. 1943. [1731]. Epitomes Historiae Missionis Lapponicae. Nordnorske Samlinger. Olso: Etnografisk Museum.

SOLANDER, C. 1910 [1727] Relation om den Norske lappmissionen och Lappernas nedendom. In: Reuterskiöld, E. Källskrifter till Lappernas mytologi. Stockholm.

STEPHANIUS, J.S. 1629. De regno Daniae et Norvegiae. Lugduni Batovorium.

STORM, G. 1881. Samlede Skrifter av. P.C. Friis. Kristiania.

1889, 1891. Den Danske geograf Claudius Clavus eller Nicolaus Niger. Ymer.

STURLUSON, S. 1970. Snorres kongesager. Heimskringla Gyldendal.

THÖRNELL, G. 1915. Veklagan öfver det lappska folkets nöd jämte Lapplands beskrifning. Jämte en inledning om författarens lif och verk, hans resa i Sverige och brefväxling med den svenska ärkebiskopen Johannes Magnus, samt andra därmed Sammanhängande amnen af E.W. Dahlgren. Uppsala.

TORNAEUS, J. 1900. [ca. 1653]. Berättelse om Lapmarckerna och Deras Tillstand. Bidrag till Kännedom om de Svenska Landsmålen och Svenskt Folkeliv XVII(3). Uppsala.

SAETER, I. 1926. Thomas von Westen. Oslo.

STEEN, A. 1954. Samenes Kristning of Finnemisjonen til 1888. Oslo.

TUDERUS, G. 1910a. [1672-1679]. En kort underrättelse om de Osterbothniske Lappar som under Kemi Gebiet lyda. Svenska Landsmål XVII(6). Uppsala.

1910b. [1685-1686]. Berättelse om prostevisitationen i Kemi Lappmark 1685-86. In: Fellman, 1. Handligar och uppsatser angående Finska Lappmårren och Lapparne. I. Helsingfors.

von WESTEN, T. 1773 [1723]. Danske Missionariens til Lappmarken, Thomas von Westens berättelse om Norska Lapparnas Widskepenser, uti Bref til Swenska Presterlaêt it Jämteland. Skrifwit år 1723. Tva Berättelser. Stockholm.

1826 [1717]. Topographia arctarchiae Danicae ecclesiatica dividendae in Lapmarkian et Finmarkian. Budstikken 2. Kristiania.

1934a [1717]. Ex Topographia Ecclesiastica Findmarkiae Thomas von Westen. Nordnorske Samlinger I. Oslo.

1934b [1717]. Topographia Ecclesiastica 2. Del: Finmarckia. Nordnorske Samlinger I. Oslo.

ZIEGLER, J. 1532. Schondia. Quae intus continentur Syria, ad Ptolomaici operis rationem...Palestina...Arabia Petrae...Aegyltus Schondia...Holmiae deplorabilis excidii per Christiernum Datiae regem, historia, Regionum superiorum, singulae tabulae Geographicae. 